\title{
Bone inside eye: choroidal osteoma presenting as exudative retinal detachment: a challenge to diagnosis
}

\author{
Srikanta Kumar Padhy, ${ }_{1}^{1}$ Sohini Mandal, ${ }^{2}$ Meghal Gagrani ${ }^{3}$
}

'Department of Ophthalmology, Dr. Rajendra Prasad Centre for Ophthalmic Sciences, AllMS, Delhi, New Delhi, India ${ }^{2}$ Department of Ophthalmology, Dr. Rajendra Prasad centre for Ophthalmic sciences, AllMS, Delhi, New Delhi, India ${ }^{3}$ Department of ophthalmology, Dr. Rajendra Prasad Centre for Ophthalmic Sciences, AllMS,

Delhi, New Delhi, India

\section{Correspondence to} Dr Srikanta Kumar Padhy, srikantkumar.padhy19@gmail. com

Accepted 30 May 2018

\section{DESCRIPTION}

A 38-year-old woman presented to outpatient department with the chief complaints of gradual onset of painless diminution of vision in the right eye since last 1 month. At presentation, the visual acuity in OD was perception of light and 20/20 in OS. Slit-lamp examination of anterior segment was found to be within normal limits in both eyes. On fundus evaluation of right eye, exudative retinal detachment ${ }^{1}$ with shifting fluid along with oedematous disc with blurry margin and juxtapapillary subretinal yellowish brown mass were noticed (figure 1A). Fundus in the left eye was within normal limits (figure 1B). With the above clinical examination, a provisional diagnosis of right-eye choroidal osteoma with exudative retinal detachment was made and confirmed on sonography, with an elevated highly reflected choroidal mass persisting at lower scanning sensitivity and acoustic shadow along with retinal detachment (figure 2A). CT scan depicted evidence of calcification (figure 2B). Fluorescein angiography of OD showed mild patchy early hyperfluorescence and diffuse intense late staining (figure 3A-C). Surface of tumour containing tufts of discrete branching vessels, which are particularly prominent in thinned out and depigmented retinal pigment epithelium areas, is a pathognomic feature of choroidal osteoma. These tuft vessels are actually feeder vessels, which emerge from the narrow spaces within the osteoma to supply the choriocapillaris present beneath Bruch's membrane of choroid. The closest differential diagnosis is choroidal haemangioma and metastatic tumours, which lacks the characteristic spider vessels seen in cohroidal osteoma. ${ }^{2}$ One of the characteristic features of choroidal osteoma is in situ calcification, which can be diagnosed using ultrasonography or CT scan. Recognition of association of serous retinal detachment should prompt the necessary investigation for possible underlying subretinal

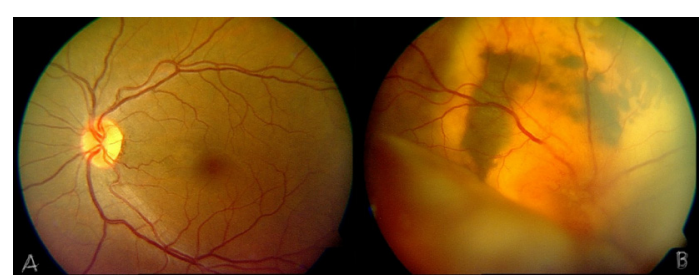

Figure 1 (A) Colour fundus photograph of OS. (B) Colour fundus photograph of OD showing exudative retinal detachment along with oedematous disc with blurry margin and juxtapapillary subretinal yellowish brown mass.

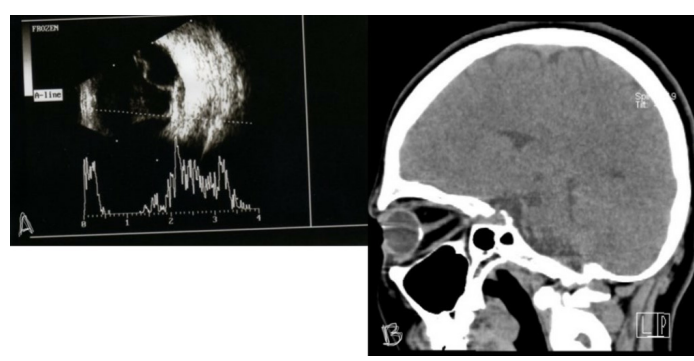

Figure 2 (A) Ultrasonography of the OD showing slightly elevated lesion with high acoustic reflectivity with acoustic shadow behind with retinal detachment. (B) CT scan head and orbit showing intraoular calcification.

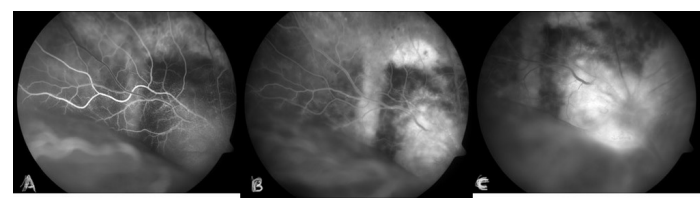

Figure 3 (A-C) Serial fundus flourescein angiography images showing mild patchy early hyperfluorescence and diffuse intense late staining.

\section{Learning points}

- Choroidal osteoma may cause severe serous retinal detachment and lead to poor prognosis.

neovascularisation, which is highly challenging in the setting of the retinal detachment.

Contributors SM: reporting, conception MG: acquisition of data, conception SKP: conception and design.

Funding The authors have not declared a specific grant for this research from any funding agency in the public, commercial or not-for-profit sectors.

Competing interests None declared.

Patient consent Obtained.

Provenance and peer review Not commissioned; externally peer reviewed.

(C) BMJ Publishing Group Ltd (unless otherwise stated in the text of the article) 2018. All rights reserved. No commercial use is permitted unless otherwise expressly granted.

\section{REFERENCES}

1 Rose SJ, Burke JF, Brockhurst RJ. Argon laser photoablation of a choroidal osteoma. Retina 1991;11:224-8.

2 Azad S, Takkar B, Venkatesh P, et al. Swept source: optical coherence tomography angiography features of choroidal osteoma with choroidal neovascular membrane, 2018. 
Copyright 2018 BMJ Publishing Group. All rights reserved. For permission to reuse any of this content visit http://group.bmj.com/group/rights-licensing/permissions.

BMJ Case Report Fellows may re-use this article for personal use and teaching without any further permission.

Become a Fellow of BMJ Case Reports today and you can:

- Submit as many cases as you like

- Enjoy fast sympathetic peer review and rapid publication of accepted articles

Access all the published articles

- Re-use any of the published material for personal use and teaching without further permission

For information on Institutional Fellowships contact consortiasales@bmjgroup.com

Visit casereports.bmj.com for more articles like this and to become a Fellow 